\title{
List of Images
}

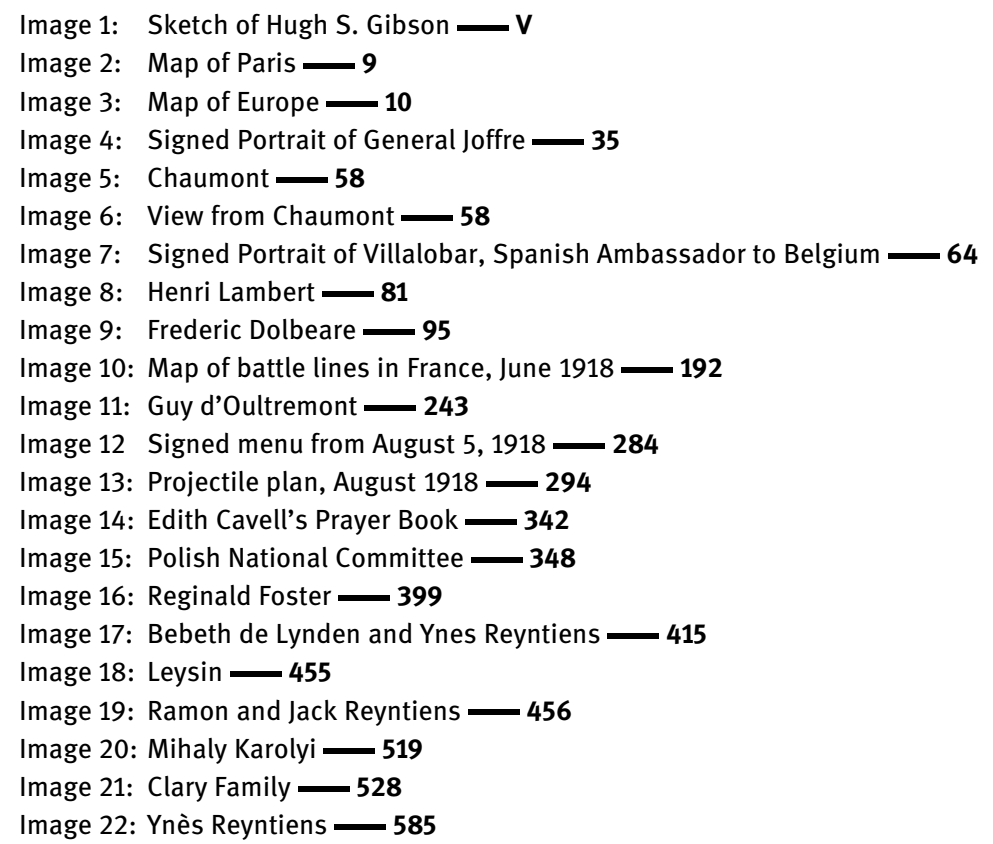


